\title{
Establishment of Learning Module based on Research of Solid Lipid Nanoparticles to Improve Biology Understanding
}

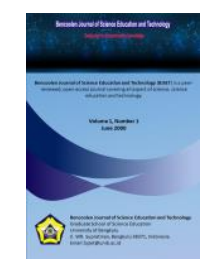

\author{
Redo* and Agus Sundaryono \\ Graduate School of Science Education, University of Bengkulu, Indonesia \\ *Email: redo90@gmail.com
}

DOI: https://doi.org/10.33369/bjset.v1i1.11186

\begin{abstract}
The goal of this study was to develop teaching materials for fat metabolism based on the effect of Caesalpinia bonduc $L$ extracted solid lipid nanoparticles on HDL and LDL levels of Mus musculus infected with malaria and improved students' understanding of the fat metabolism concept for Biology Education students in animal physiology courses at Bung Hatta University, Padang. The development model used is Research and Development R\&D adapted from the stages (R\&D) by Borg and Gall. Research conducted by analyzing the needs of students in the learning process of animal physiology in obtaining information and knowledge which used as modules for learning resources. The trial modules were conducted to 18 students of Biology Education at Bung Hatta University, Padang. The results showed that the students' understanding of the concept of fat metabolism using the fat metabolism module was very varied, the understanding of the concept of fat metabolism was mostly categorized as good (39\%), adequate (36\%) and less adequate (25\%). The ability to understand the concept of fat metabolism of students on the translational aspect has developed well, interpretation was sufficient while extrapolation has not developed well. This fat metabolism module improved the ability to understand the metabolic fat concepts of students of Biology Education at Bung Hatta University viewed value classically.
\end{abstract}

Keywords: Learning resources, C. bonduc, solid lipid nanoparticles, module, concept understanding.

\section{INTRODUCTION}

Indonesia is known to have abundant bio-diversity, several studies have been mentioned that of around 30,000 plant species in Indonesia as many as 6,000 species are nutritious plants that can be used as medicine. According to Notoatmodjo (2007), plants in Indonesia reached 7,000 species, and 1,000 species of these plants are used to prevent and treat disease. The rapid development of globalization is leading humans to the advancement of technology especially in the field of modern medicine, so, the humans are accustomed to using synthetic medicine, and forgetting traditional methods by using plants as natural medicine. Treatment using 
synthetic medicine or chemical drugs have dangerous side effects if used continuously, in contrast, with traditional medicine, according to Thomas (1989), the use of traditional medicines has good advantages that have smaller side effects when compared to chemical treatment. Concerning of herbal or natural remedies, actually, there are many plants can be used as natural ingredients for treatment around our homes, one of them is Caesalpinia bonduc L.

$C$. bonduc $L$ has several chemical compounds that have many medicinal benefits. Kusrahman (2012) has conducted research on whistle, on the phytochemical test results of $C$. bonduc $L$ plants revealed that this plant contains several secondary metabolite compounds including flavonoid compounds, alkaloids, steroids, triterpenoids. The use of $C$. bonduc $L$ as a drug was obtained from the empirical experience of some people who often use this plant. Generally, the part of C. bonduc $\mathrm{L}$ that is used as medicine is the substance of whistle seeds which has antimicrobial activity, antioxidants, and cytotoxic effects derived from the flavonoid substance.

Public knowledge about the benefits of metabolite compounds in whistle plants for the human body is still lacking, especially in Bengkulu Province. Therefore, it is necessary to provide an understanding or knowledge about the benefits of whistle plants to the public through a learning process of utilizing these plants, especially in the field of biology. This is because biology has an involvement in the development of applied sciences such as health which has driven the development of medicines from natural materials, including improving quality, safety, finding new indications, and formulations. In this case, learning Animal Physiology is the right place because this learning is closely related to biology that studies the structure and function of cellular components, such as proteins, carbohydrates, lipids, nucleic acids, and other biomolecules. The learning process in higher education has an important role in conveying knowledge to students, so that the media needs to contains information and ideas that are able to facilitate student learning, namely learning resources (Sitepu, 2008). Learning resources are not only obtained from lecturers and theoretical books or textbooks but also obtained from the surrounding environment. This is in line with the opinion of Brahim (2007) which states that the existence of natural surroundings is a potential that can be used to support the activities of students in the learning process.

Development of teaching materials especially modules is one way that can be considered in solving these problems. It must be able to answer and solve problems of difficulties in learning. Module is a printed teaching material in the form of sheets of paper containing material, summaries, and instructions for the implementation of learning tasks that must be carried out by students that refer to the basic competencies that must be achieved (Prastowo, 2013). Competence in terms of conceptual understanding is expected by having the module able to provide understanding to students (Depdiknas, 2008).

\section{RESEARCH METHODS}

The method of development in this research used Research and Development (R\&D). Design experiment in this research used essay questions. The research subjects were Biology 
Education students at Bung Hatta University, totalling 18 students. This research and development site were carried out at Bung Hatta University, Padang.

The procedure of Metabolism Module product development in this study consists of four stages due to limited time and resources, namely: research and information gathering, planning, product draft development, and initial field trials. The instrument used to collect research and development data on fat metabolism teaching materials is a test (Handayani, 2014). The data analysis technique used is descriptive and quantitative analysis techniques.

The stages of developing the fat metabolism module in the University of Bung Hatta University biology study program students are as follows:

1. Requirement Analysis Phase

This stage begins by analysed, animal physiology learning activities, observing and conducting field surveys in the Biology Education Study Program at Bung Hatta University, Padang.

2. Design Development Stage

Designing research about the effect of dense extract lipid nanoparticles (Caesalpinia bonduc $L$ ) on HDL and LDL levels of mice infected with malaria.

3. Module Design

The results of the research carried out in the previous stage will be implemented into the preparation of teaching materials in the form of the Fat Metabolism Module to support lecturers or educators in carrying out the teaching and learning process.

4. Design Validation

Activities to assess the effectiveness of product design. In this research, product validation was carried out by 3 lecturers namely media experts, material experts and education practitioners. The results of the validation are used as a basis for making improvements to the development.

\section{Design Revision}

At this stage, the module is produced after validation by experts. The weaknesses of the Module will be fixed.

6. Trial usage

The process of applied modules in learning process. The experiment was conducted to students by giving six essay questions to see the understanding of student concepts with indicators of installation, interpretation and extrapolation (Millar, 2017).

\section{RESULTS AND DISCUSSION}

The data obtained in this study to improve understanding of concepts through the Metabolism Module in the biology student of Hatta Hatta were:

\section{Need analysis}

The results of the analysis in learning Animal Physiology were still dominated by the percentage and discussion of groups that have been designed by lecturers. The application of percentage learning and group discussion did not show varied and innovative characteristics in 
the material or concept. The results of preliminary studies showed that teaching materials are dominated by books on Animal Physiology from several publishers. The used of teaching materials developed from research results sourced from the local potential of the surrounding environment has never been available in Animal Physiology courses. The used of local potential in learning can be packaged in a research-based module. The research-based module is prepared by paying attention to the presence or absence of local potential that is used as a learning resource.

2. Design Development Stage

Based on the results of the needs analysis, this stage begins with the extract of Caesalpinia bondul $L$ solid nanoparticles on the levels of malaria-infected HDL and LDL as a reference for developing Module materials (Mehnert, 2001; Fazrin, 2020).

3. Product Design

Product development in the form of teaching materials in the form of Modules whose component contents of the module consists of learning activities, test questions, and evaluations, learning activities consist of two activities namely (1) metabolic material, (2) metabolic relationships in plant whistle.

\section{Design Validation}

Based on the results of the study, it was found that the module design according to the validator's assessment had a decent qualification and could be used in learning animal physiology. The percentage of figures can be seen in Table 1 as follows.

Table 1. Metabolism Module validation test results

\begin{tabular}{ccc}
\hline Validator & Percentage & Category \\
\hline Material & 80 & Decent \\
Media & 82 & Very decent \\
Practitioners & 80 & Decent \\
\hline
\end{tabular}

Module Design as a teaching material Animal physiology that has been evaluated by the validator as a whole does not need to be revised. However, revisions are still made based on the advice given by each expert, either directly or in writing in the advice column. The Metabolism Module printed and implemented in animal physiology learning of fat metabolism material in biology students of Bung Hatta University, Padang.

5. Design Revision

At this stage, improvements/revisions were made to the learning tools that had been validated by experts, the results of the study showed that teaching materials developed at Bung Hatta University reached $80.66 \%$ with good qualifications. This showed that the Metabolism Module can be used in learning animal physiology.

\section{Usage Trial}

The results of trials understanding the concept of fat metabolism through Modules are presented in Table 2. Understanding concepts were the ability to capture notions such as 
expressing a material presented in a form was better understood than material learned from the learning process. This ability was expressed in translation (translating), interpretation (interpretation), and Extrapolation (estimation).

Percentage of understanding of the concept of fat metabolism of students of Biology at Bung Hatta University after using the Development Modules of 39\% for translation, 36\% for interpretation, and $25 \%$ for extrapolation. The percentage showed learning with teaching materials. Module-based on research development can improve understanding of concepts, especially on indicators of translation and interpretation but still needs to be improved in extrapolation. In this study, students trained to construct knowledge through solving problems related to local potential in daily life. Teaching with module teaching materials can help students develop concepts, so that, they can bridge theoretical knowledge and real experience.

Table 2. The results of score and category

\begin{tabular}{ccc}
\hline Indicator & Score & Category \\
\hline Translation & 80.56 & Good \\
Interpretation & 75.00 & Adequate \\
Extrapolation & 52.78 & Less \\
\hline
\end{tabular}

\section{CONCLUSION}

The results showed that the teaching materials in the form of Modules met the validation criteria of $80.56 \%$ with decent qualifications. This research-based Metabolism Module was able to develop an understanding of the concept of fat metabolism. Students of Biology Education at Bung Hatta University in Padang were result in classical values with category $39 \%$ good, $36 \%$ adequate, and $25 \%$ less adequate.

\section{REFERENCES}

Depdiknas. (2008). Panduan Penulisan Modul. Direktorat Tenaga Kependidikan Direktorat Jenderal Peningkatan Mutu Pendidik dan Tenaga Kependidikan Depdiknas.

Fazrin, E. I., Naviardianti, A. I., Wyantuti, S., Gaffar, S., \& Hartati, Y. W. (2020). Sintesis Dan Karakterisasi Nanopartikel Emas (AuNP) Serta Konjugasi AuNP Dengan DNA Dalam Aplikasi Biosensor Elektrokimia. PENDIPA Journal of Science Education, 4(2), 21-39.

Handayani, S. (2014). Pengembangan Modul Pembelajaran Berbasis Pengujian di Laboratorium sebagai Upaya Peningkatan Kompetensi. Prosiding Konvensi Nasional Asosiasi Pendidikan Teknologi dan Kejuruan (APTEKINDO). 5(7): 805-1000.

K. Brahim, Theresia. (2007). Peningkatan Hasil Belajar Sains Siswa kelas IV Sekolah Dasar, melalui Pendekatan Pemanfaatan Sumber Daya Alam Hayati di Lingkungan Sekitar. Jurnal Pendidikan Penabur, 9(6), 4.

Kusrahman, A., (2012) Isolasi, karakterisasi senyawa aktif dan uji farmaka ekstrak biji kebiul pada mencit (Mus musculus) serta penerapannya dalam pembelajaran kimia di SMAN 1 
Bengkulu Selatan, Tesis, Pasca Sarjana (S2) Pendidikan IPA, Keguruan dan Ilmu pendidikan Universitas Bengkulu, Bengkulu. Indonesia.

Mehnert, W. dan Mader, K. (2001). Solid lipid nanoparticle Production, characterization and applications. Advanced Drug Delivery Reviews. 47(1): 165-196.

Millar CL, Duclos Q, and Blesso CN. (2017). Effects of Dietary on Reverse Cholesterol Transport, HDL Metabolisme, and HDL Function. Department of Nutritional Sciences, University of Connecticut, Storrs, CT.

Notoatmodjo, S. (2007). Kesehatan Masyarakat Ilmu dan Seni. Jakarta: Rineka Cipta.

Prastowo, Andi. (2013). Panduan Kreatif Membuat Bahan Ajar Inovatif. Yogyakarta: Diva Press.

Sitepu, (2008). Pengembangan Sumber Belajar. Jakarta: Guru Besar Universitas Negeri Jakarta. Jurnal Pendidikan Penabur, 8(11), 88-89.

Thomas, A.N.S., (1989), Tanaman Obat tradisional, Kanisius, Yogyakarta. 